other mammals. In that state it could perhaps maintain itself for a long period of time, even though relegated to the less favorable parts of the world.

Without transcending the path already laid out in previous geologic periods, we may logically imagine also, that in due course of time - probably to be measured in millions of years, an entirely new and more highly organized animal may spring from some ancestral stock now relatively obscure, and rise, at first slowly and then more rapidly, to even greater heights of achievement than anything which lies within the eapacity of the human species.

We have briefly examined the sequence of physical events in the earth's history and have found but scant indication of a definite trend toward an objective point. In the history of man and other organisms we seem to see, on the other hand, an evolution from the lower to the higher-from the simpler to the more complex. To that extent there has been quite evidently a general upward curve. It seems probable, however, that the quantity of organic life has remained more or less the same since very early times. There has been the age-long tendency for each species to multiply until its possible habitat was fully stocked with individuals. As periods came and went new types appeared and extended their realms, like wave-circles on the still surface of a pond, but compensating extinctions of older types left room for them. One may picture even the organic world as a stream, unchanging in volume, though 'ever changing in composition; and its end is to us still as invisible as its beginning.

HARVARD UNIVERSITY

ELIOT BLACKWELDER

\section{THE AGRICULTURAL MUSEUM OF THE ARGENTINE RURAL SOCIETY}

MUSEums devoted strictly to agriculture are rare. The only one in the Western Hemis-

1 Museo Agricola de la Sociedad Rural Argentina “Fundacion Organizacion Muestrarios," Ing. Agr., Carlos D. Girola 1910-Director Honorario1921. Publicacion Museo Agricola S. R. A. No. 25. phere, founded and organized as such, is located in the metropolis of the Argentine Republic. An illustrated pamphlet of fifty pages describing the museum and briefly outlining its collections has been published ${ }^{1}$. It is in a series of publications issued by the museum, and forms the basis of this communication.

Argentina is preeminently an agricultural country. More than half its cultivated area, $64,225,000$ acres, is devoted to the growth of wheat, Indian corn, oats and flax (for seed). Its vineyards occupy 345,800 acres while $24,700,000$ acres are in alfalfa. Cattle and other domestic animals number about $92,300,000$ and in 1918 Argentina exported 1,479,618,000 pounds of meat.

The collections made to illustrate the agricultural resources of the country at the centennial exposition,. held in Buenos Aires in 1910, were so extensive and valuable that a permanent museum was established in which to preserve them. The success which has attended the foundation and organization of the museum is due chiefly to the foresight and untiring energy of Sr. Carlos D. Girola, agricultural engineer, who has been its honorary director from its origin. $\mathrm{He}$ has built up, without guide or precedent, an institution of the greatest value in promoting the agricultural interests of his country. The museum now contains more than 30,000 specimens, covering the entire field of agriculture and is one of the most comprehensive of its type in the world.

The collections are classified in seven groups or divisions as follows:

1. Natural Products, such as woods, native medicinal and forage plants, minerals, soils, mineral waters, etc.

2. Agricultural Products, including everything produced on the farm such as wheat and other cereals, vegetables, narcotic and aromatic plants, fiber plants, etc. In this group the museum contains 6,000 specimens.

3. Products of Animal Origin, wool, hides, leather, etc.

4. Products of Agricultural Industry, flour, sugar, tannin, dried and canned fruits and vegetables, etc.

5. Products of Animal Industry, milk, butter, cheese, bees and bee products, poultry and 
poultry products, silk culture, game, fish, diseases of animals, etc.

6. Agricultural Machinery, tools and appliances used in agriculture.

7. Rural Engineering, under which are placed all subjects relating to farm buildings, construction of granaries, ete.

In the organization of the museum provision is made for the holding of agricultural congresses or meetings for the purpose of discussing subjects relating to agriculture, and for the issuing of publications and making exchanges. Up to the present time the publications include twenty-five titles, most of which have been prepared by Sr. Girola. Among the subjects treated are: "Studies of Cotton," "Observations on samples of wheat from the Territory of Pampa," "The Cultivation of Wheat in Argentina," "Spineless Cactus," "Cultivation of Flax in Argentina," "Cultivation of Indian Corn in Argentina," "Notes on Argentine Fruit Culture," etc. For the most part these papers are based on the collections of the museum.

The supervision of this museum is under the directors of the Argentine Rural Society. The museum staff consists of the honorary director, curator, assistant curator and two caretakers.

The museum building is located on the grounds of the Rural Society, in a very attractive section of Buenos Aires, overlooking Plaza Italia. It is 300 feet long by 90 feet wide and originally cost $\$ 100,000.00$. The interior which is well lighted, consists of a main floor surrounded by a broad balcony.

The annual attendance at the museum, which is open to the public two days each week, exceeds 100,000 not including the $30_{2} 000$ students which visit it from the schools of Buenos Aires. These figures demonstrate the interest which the museum has aroused and the need for such an institution.

The illustrations in the pamphlet before us include the museum building, its floor plan and twenty full page views of the interior, showing many of the exhibits and the manner in which they are installed. The collections have far outgrown their present accommodations, and plans have been prepared for additional building to take care of the agricultural machinery and other new material.
Besides the agricultural museum at Buenos Aires there are the Danish Agricultural $\mathrm{Mu}$ seum at Lyngby, near Copenhagen, established in 1888; the Agricultural Museum at Petrograd, about which little is known at the present time; the large and well-equipped museum at Berlin, and the attractively located and wonderfully interesting museum at Budapest. The buildings of this museum at Budapest, constructed at a cost of $\$ 480,000.00$, are so designed as to illustrate the Renaissance and medieval periods of architecture of Hungary. Their interiors are superbly finished, and the collections, which may be said to include the agricultural features of museums of art, history and anthropology, natural history and commerce, are appropriately and beautifully installed in the many welllighted rooms into which the Renaissance and Gothic buildings are divided.

The museum at Buenos Aires should not be compared with those institutions which have been built and liberally supported by the state. Great riches are not indispensable. An agricultural museum properly located for meeting its purposes would, by well directed effort and with the friendly cooperation of those engaged in agricultural industries, quickly secure collections. With such collaboration an equipment may be acquired that will equal or possibly excel in practical importance that which money could buy.

Like Argentina in South America, Hungary in Europe is essentially an agricultural country, and it is interesting to note that in the one case the material and exhibits that formed the basis of its collections were assembled for an exposition commemorating the hundredth anniversary of the country's existence as a nationin the other instance the collections commemorated its thousandth anniversary, the National Millennial Exposition held at Budapest in 1904. Our hundredth anniversary, commemorated by the exposition held at Philadelphia in 1876, has passed. Argentina has outstripped us in its agricultural development by the establishment of a permanent agricultural museum. Without any reflection upon the progress and present status of agriculture in Hungary, which is most commendable, let us hasten to follow the example of our sister Republic in South America 
and not wait for our milennial anniversary before establishing a great American Museum of Agriculture.

WASHINGTON, D. C.

OCTOBER 21, 1921

\section{SCIENTIFIC EVENTS}

\section{THE WILLIAM BARTON ROGERS SCIENCE HALL OF THE COLLEGE OF WILLIAM AND MARY}

AN advisory committee of prominent men, most of whom are trustees. or alumni of the Massachusetts Institute of Technology, has been formed in the interests of a movement to provide for the erection at the College of William and Mary, in Virginia, of the William Barton Rogers Memorial Science Hall, in honor of the William and Mary graduate who founded the Massachusetts Institute of Technology.

The members of the committee are T. Coleman DuPont, Wilmington, Del., Charles W. Eliot, Cambridge, Mass.; Samuel Morse Felton, Chicago, Ill.; Francis Russell Hart, Boston, Mass.; Charles Hayden, New York, N. Y.; Otto H. Kahn, New York, N. Y.; Hugh MacRae, Wilmington, N. C.; Eliakim Hastings Moore, Chicago, Ill.; James P. Munroe, Boston, Mass.; Henry Smith Pritchett, New York, N. Y.; Charles Augustus Stone, New. York, N. Y.; Gerard Swope, New York, N. Y.; Elihu Thomson, Swampscott, Mass.; Charles Doolittle Walcott, Washington, D. C.; Edwin Sibley Webster, Boston, Mass.

The College of William and Mary is the second oldest college in the United States, yielding only to Harvard University in this respect. President Harding, on a visit to the college on October 19 last, in company with Secretaries Hughes, Hoover, Mellon and Weeks, of his cabinet, was greatly impressed with the traditions and present progress of the venerable institution. $\mathrm{He}$ referred to the college as 'the Spartan of American universities," having in mind, no doubt, the successful effort of William and Mary to endure after its burning in the Civil War, in 1862, shortly after Dr. Rogers had established in Boston the great technical school.

William Barton Rogers was one of four brothers, who were educated at William and
Mary, each in later life achieving great distinction in a chosen field of science. $\mathrm{He}$, himself, as a geologist, was noted in Virginia long before he went to Boston. He was the introducer of the laboratory method of teaching science in this country, according to Dr. Charles W. Eliot, who was one of his original faculty at the Institute of Technology. The three other brothers were Henry D. Rogers, who became regius professor of natural history in the University of Glasgow, Scotland; James Blythe Rogers, professor of chemistry in the University of Pennsylvania; and Robert Empie Rogers, professor of toxicology in the Jefferson Medical College of Philadelphia.

The sum of $\$ 200,000$ has been set as the amount needed for building the Science Hall, which is designed to commemorate the bond of friendship between the South's oldest college and the North's foremost institution of technology. Contributions may be sent to E. B. Thomas, alumni director, 331 Madison Avenue, New York City.

\section{RETIREMENT OF PROFESSOR ALBERT W. SMITH OF CORNELL UNIVERSITY}

THE following minute has been adopted by the University Faculty of Cornell University on the occasion of the retirement of Professor Albert W. Smith :

In the retirement from his academic functions of Albert William Smith, dean of Sibley College and acting president of the university, this faculty suffers a heavy loss. Few have been so universally, so deeply, so deservedly loved. An alumnus of Cornell in the first decade of her career, he was from early in his undergraduate days a leader both in study and in manly sports, and one whom his fellows delighted to honor. Returning to Cornell in 1886 for graduate study, he was not again suffered to depart from academic life. From 1887 to 1891 he taught engineering at Cornell, in 1891-1892 at the University of Wisconsin, from 1892 to 1904 was head of the work in mechanical engineering at Stanford. Since 1904, when he was called back to Cornell to succeed Dr. Thurston in the headship of Sibley College, he has remained with his alma mater, adding to his directorship the chair of power engineering; and in 1920, at the retirement of Dr. Schurman, he became acting president of the university.

With what loyalty and efficiency he has dis- 